\title{
Nicotine Chewing Gum and Its Correlation with Smoking Cessation: A Meta-Analysis
}

\author{
Roni Hartono', Lina Eta Safitri²) \\ 1)Faculty of Psychology, Universitas Teknologi Sumbawa, Indonesia \\ ${ }^{2)}$ Masters Program in Public Health Masyarakat, Universitas Sebelas Maret
}

\section{ABSTRACT}

Background: Smoking is a human behavior that has a very bad impact on health. Mortality and morbidity due to smoking cannot be underestimated. Non-communicable diseases become high morbidity among smokers, such as diabetes, reduced fertility, coronary heart disease, and countless health complications. This study aims to analyze the effect of the use of nicotine gum on the success of smoking cessation based on a number of previous similar studies.

Subjects and Method: This is a systematic review and meta-analysis conducted by following the PRISMA flow diagram. The process of searching for articles through a journal database which includes: Google Scholar by selecting articles published in 2010-2020. With keywords, among others: "Nicotine Replacement Therapy" OR Gum Nicotine-" AND "Smoking cessation. The inclusion criteria were full paper articles with experimental study design, articles in English, bivariate analysis with Odds Ratio. Eligible articles were analyzed using the Revman 5.3 app.

Results: A total of five articles were reviewed in this study using a randomized controlled trial design. A meta-analysis of five randomized controlled trials showed that 0.81 times the use of nicotine gum did not help smokers quit smoking compared with placebo (OR $0.81 ; 95 \% \mathrm{CI} 0.48$ to 2.12; $\mathrm{p}=0.400$ ).

Conclusion: Nicotine gum does not help smokers to quit smoking.

Keywords: Gum Nicotine, smoking cessation, Smoke

\section{Correspondence:}

Roni Hartono. Faculty of Psychology, Universitas Teknologi Sumbawa, Jl. Raya Olat Maras, Batu Alang, Moyo Hulu, 84371, Sumbawa Besar. Email: roni.hartono@uts.ac.id

\section{Cite this as:}

Hartono R, Lina Eta Safitri LE (2021). Nicotine Chewing Gum and Its Correlation with Smoking Cessation: A Meta-Analysis. J Epidemiol Public Health. 06(02): 170-176. https://doi.org/10.26911/jepublichealth.2021.06.02.04.

\section{BACKGROUND}

Smoking is a human behavior that has a very bad impact on health, especially the risk of various diseases that are very dangerous and deadly. Smoking has a double danger that it can be dangerous for the smoker himself and for passive smokers around him. Passive smokers are people who do not smoke but inhale cigarette smoke from other people around them (Taringan. 2019)
The case of cigarette users in the world can be said to be quite high, it can be seen that about $23 \%$ of the world's population smokes. Where $32 \%$ of them are male and the highest prevalence is in Indonesia, while there are $7 \%$ of smokers who are female. Indonesia is a developing country that has a threat of serious cigarette consumption problems, where the prevalence of smokers in Indonesia has increased, which occurred in smokers aged 18 years from $7.2 \%$ increasing to $9.1 \%$ 
(Adam et al. 2010; Indonesian Ministry of Health 2018).

The death rate from cigarettes in Indonesia is increasing as evidenced by 2015 there were more than 130,000 due to tobacco consumption every year. Mortality and morbidity due to smoking cannot be taken for granted. Non-communicable diseases are a very high morbidity among smokers, such as diabetes, reduced fertility, coronary heart disease, and countless health complications (Martin et al. 2019).

Meta-analysis is an epidemiological design that aims to systematically examine and combine quantitative estimation results from a number of previous studies that answer the same research problem and can be combined. Many primary studies have investigated the effect of NRT on smoking cessation success. Further analysis is needed to arrive at a convincing conclusion. Based on this background, the researcher is interested in conducting a systematic review and meta-analysis on "The Effect of Nicotine Chewing Gum on the Success of Quitting Smoking".

\section{SUBJECTS AND METHOD}

\section{Study Design}

This study is a systematic review and metaanalysis. The articles used in this study were obtained from the database, namely Google Scholar. With keywords including: "Nicotine Replacement Therapy" OR Gum Nicotine" AND "Smoking cessation"

\section{Inclusion Criteria}

Inclusion criteria for articles that can be reviewed are full paper articles with experimental study designs, articles using English, bivariate analysis with Odds Ratio, intervention given nicotine gum, research subjects are smokers, outcome is smoking cessation.

\section{Exclusion Criteria}

The articles published in this study are articles that have been meta-analyzed and qualitative studies have been carried out. The article is published other than in English with results not Odds Ratio.

\section{Operational Definition of Variables} The search for articles was carried out by considering the eligibility criteria defined using the PICO model. The population in this study were adult smokers with an intervention in the form of gum nicotine, comparison was a placebo and the outcomes of successful smoking cessation.

Nicotine gum is the administration of nicotine therapy to stop smoking in adult smokers in the form of nicotine gum.

Quitting smoking is the ability of smokers not to smoke after taking nicotine therapy to quit smoking.

\section{Data Analysis}

Data processing was carried out by Review Manager (RevMan 5.3) by calculating effect size and heterogeneity to determine the combined research model and form the final result of the meta-analysis.

\section{RESULTS}

The process of searching for articles by searching through the database according to the PRISMA flow diagram. The initial search process in the database resulted in 857 articles and there were additional 43 articles identified from other searches, articles with 900 filtered articles of which met the requirements for further full text reviews, can be seen in Figure 1.

Research related to the effect of gum nicotine on smoking cessation success consisted of 5 articles from 3 continents of North America, and 2 from Asia

The interpretation of the results of the meta-analysis can be seen through the forest plot in Figure 3 shows that the use of chewing gum can increase the success of 
smoking cessation. The results of a metaanalysis in a randomized controlled trial showed that the use of gum nicotine increased smoking cessation success as much as 0.81 times and did not help smokers quit smoking compared to placebo (OR $0.81 ; 95 \%$ CI 0.48 to $2.12 ; \mathrm{p}=0.400$ ). The heterogeneity of the research data shows I $2=68 \%$ so that the distribution of the data is declared heterogeneous (random effect model)

Based on Figure 4, it shows that there is a publication bias which is indicated by the asymmetry of the right and left plots where 2 plots are on the right and 3 plots are on the left. Bias also occurs from the imbalance between the distances between studies on both the right and left sides of the funnel plot.

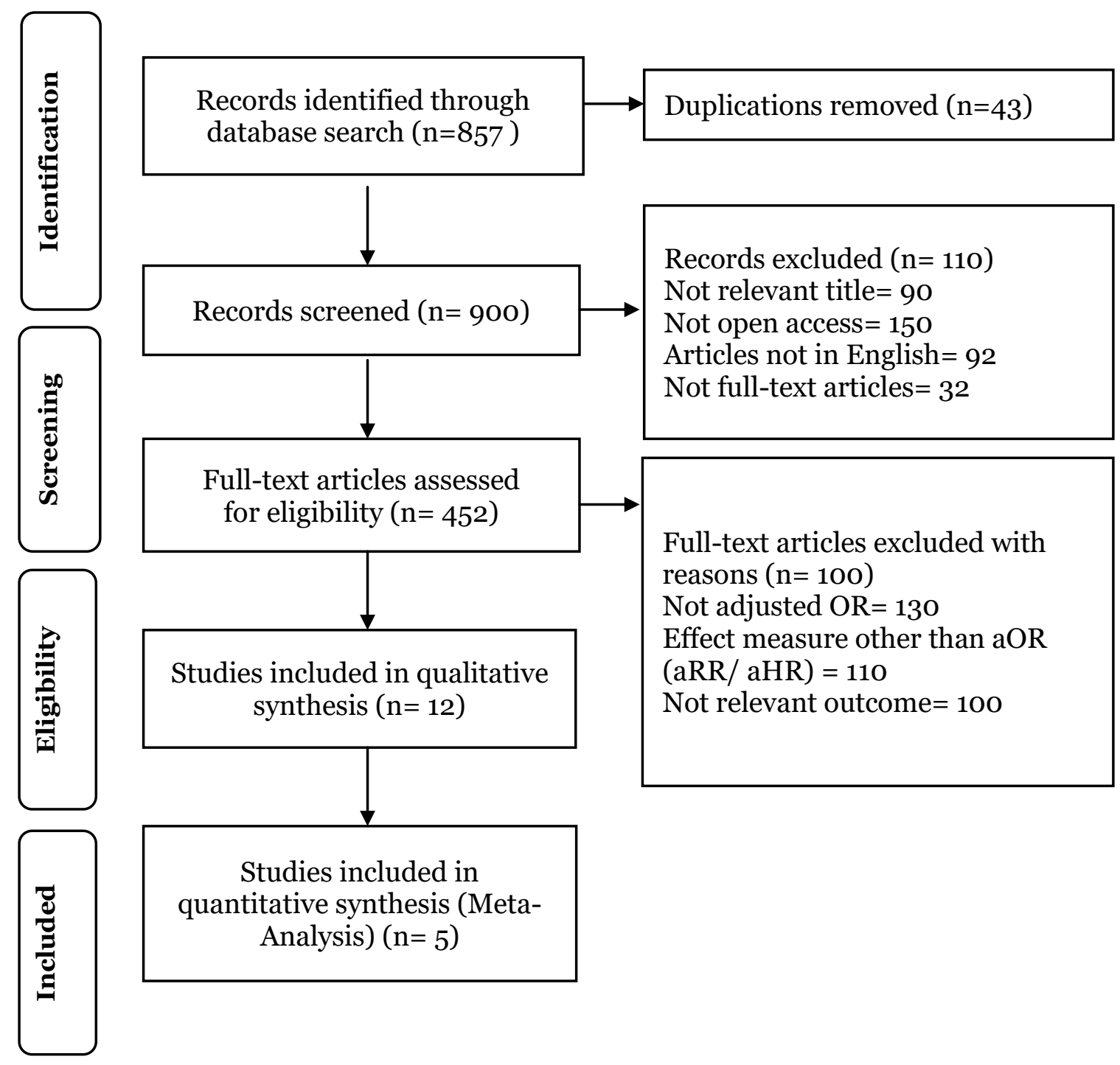

Figure 1. Prisma Flow Diagram 


\section{Table 1. Assessment of Research Quality using Critical Appraisal Questions for Randomised Controlled Trial}

\begin{tabular}{|c|c|c|c|c|c|}
\hline Questions of checklist & $\begin{array}{c}\text { Aung et al. } \\
(2019)\end{array}$ & $\begin{array}{l}\text { Costello et } \\
\text { al. (2010) }\end{array}$ & $\begin{array}{l}\text { Saul et al. } \\
\text { (2019) }\end{array}$ & $\begin{array}{l}\text { Shiffan et } \\
\text { al. (2019) }\end{array}$ & $\begin{array}{c}\text { Leung et al. } \\
(2019)\end{array}$ \\
\hline Did the trial address a clearly focused issue? & 1 & 1 & 1 & 1 & 1 \\
\hline Was the assignment of patients to treatments randomized? & 1 & 1 & 1 & 1 & 1 \\
\hline Were all of the patients who entered the trial properly accounted for at its conclusion? & 1 & 1 & 1 & 1 & 1 \\
\hline Were patients, health workers and study personnel "blind" to treatment? & 1 & 1 & 1 & 1 & 1 \\
\hline Were the groups similar at the start of the trial & 1 & 1 & 1 & 1 & 1 \\
\hline Aside form the experimental intervention, were the groups treated equally? & o & 1 & 1 & 1 & 1 \\
\hline How large was the treatment effect? & 1 & 1 & 1 & 1 & 1 \\
\hline How precise was the estimate of the treatment effect? & 1 & 1 & 1 & 1 & 1 \\
\hline Can the results be applied to the local population, or in your context? & 1 & 1 & 1 & 1 & 1 \\
\hline Were all clinically important outcomes considered? & 1 & 1 & 1 & 1 & 1 \\
\hline Are the benefits worth the harms and costs? & 1 & 1 & 1 & 1 & 1 \\
\hline Total & 10 & 11 & 11 & 11 & 11 \\
\hline
\end{tabular}

Answer: 1 Yes, $\mathrm{O}=$ No

Table 3. Description of the primary studies included in the meta-analysis

\begin{tabular}{|c|c|c|c|c|c|c|c|c|}
\hline $\begin{array}{l}\text { Author } \\
\text { (Year) }\end{array}$ & Title & Country & $\begin{array}{l}\text { Study } \\
\text { Design }\end{array}$ & $\begin{array}{l}\text { Sam } \\
\text { ple }\end{array}$ & $\stackrel{\mathbf{P}}{\text { Population }}$ & $\begin{array}{c}\text { I } \\
\text { Inter- } \\
\text { vention }\end{array}$ & $\begin{array}{c}\text { C } \\
\text { Compa } \\
\text { rison } \\
\end{array}$ & $\begin{array}{l}\text { O } \\
\text { Outcome }\end{array}$ \\
\hline $\begin{array}{l}\text { Aung et al } \\
(2019)\end{array}$ & $\begin{array}{l}\text { Effectiveness of a new multi-component smoking cessation } \\
\text { service package for patients with hypertension and diabetes in } \\
\text { northern Thailand: a Randomized controlled trial (EACAPE } \\
\text { study) }\end{array}$ & Thailand & RCT & 319 & $\begin{array}{l}\text { Adult Smoker } \\
\text { Age } 18 \text { Years }\end{array}$ & $\begin{array}{l}\text { Gum } \\
\text { Nicotine }\end{array}$ & placebo & $\begin{array}{l}\text { Quit } \\
\text { smoking }\end{array}$ \\
\hline $\begin{array}{l}\text { Costello } \\
\text { et al } \\
(2010)\end{array}$ & $\begin{array}{l}\text { Effectiveness of pharmacist counseling combined with } \\
\text { nicotine replacement therapy: a pragmatic randomized trial } \\
\text { with } 6,987 \text { smoker }\end{array}$ & Canada & $\mathrm{RCT}$ & $\begin{array}{c}6,98 \\
7\end{array}$ & $\begin{array}{l}\text { Adult Smoker } \\
\text { Age } 18 \text { Years }\end{array}$ & $\begin{array}{l}\text { Gum } \\
\text { Nicotine }\end{array}$ & placebo & $\begin{array}{l}\text { Quit } \\
\text { smoking }\end{array}$ \\
\hline $\begin{array}{l}\text { Saul et al } \\
(2019)\end{array}$ & $\begin{array}{l}\text { Using Nicotine Gum to Assist Nondaily Smokers in Quitting : } \\
\text { A Randomized Clinical Trial }\end{array}$ & USA & RCT & 369 & $\begin{array}{l}\text { Adult Smoker } \\
\text { Age } 18 \text { Years }\end{array}$ & $\begin{array}{c}\text { Gum } \\
\text { Nicotine }\end{array}$ & placebo & $\begin{array}{c}\text { Quit } \\
\text { smoking }\end{array}$ \\
\hline $\begin{array}{l}\text { Shiffan et } \\
\text { al (2019) }\end{array}$ & $\begin{array}{l}\text { Effectiveness of nicotine Gum in Preventing lapses in the face } \\
\text { of temptation to some among non-daily smoker: a secondary } \\
\text { analysis }\end{array}$ & USA & $\mathrm{RCT}$ & 255 & $\begin{array}{l}\text { Adult Smoker } \\
\text { Age } 18 \text { Years }\end{array}$ & $\begin{array}{l}\text { Gum } \\
\text { Nicotine }\end{array}$ & placebo & $\begin{array}{l}\text { Quit } \\
\text { smoking }\end{array}$ \\
\hline $\begin{array}{l}\text { Leung et } \\
\text { al (2019) }\end{array}$ & $\begin{array}{l}\text { Combine nicotine patch with gum versus nicotine patch alone } \\
\text { in smoking cessation in Hong Kong primary care clinics: a } \\
\text { randomised controlled trial }\end{array}$ & $\begin{array}{l}\text { Hong } \\
\text { Kong }\end{array}$ & RCT & 560 & $\begin{array}{l}\text { Adult Smoker } \\
\text { Age } 18 \text { Years }\end{array}$ & $\begin{array}{c}\text { Gum } \\
\text { Nicotine }\end{array}$ & placebo & $\begin{array}{c}\text { Quit } \\
\text { smoking }\end{array}$ \\
\hline
\end{tabular}


Hartono et al./ Nicotine Chewing Gum and Its Correlation with Smoking Cessation

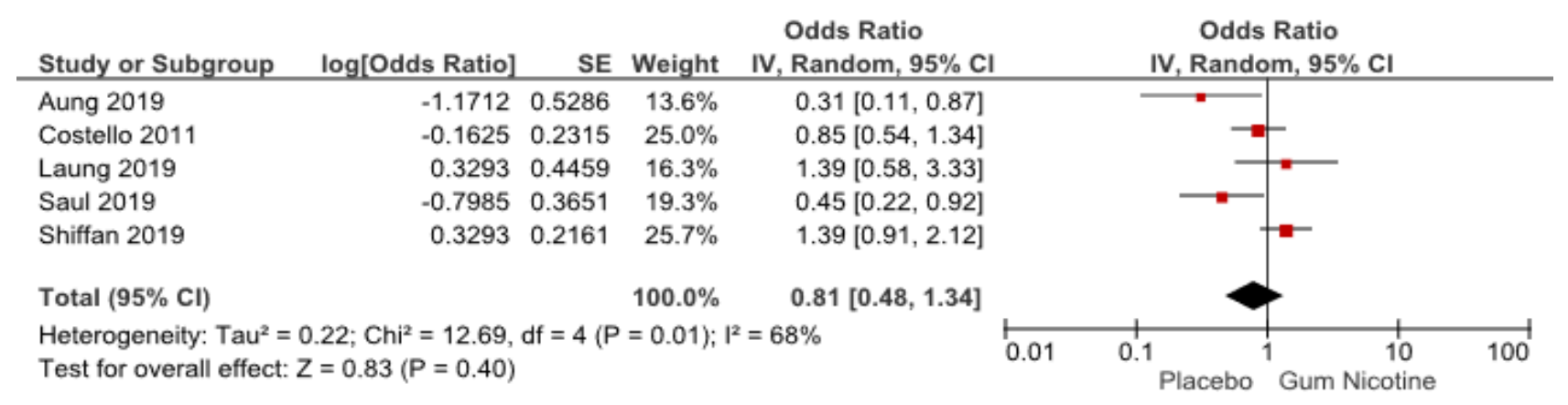

Figure 3. Forest Plot Effect of Nicotine Chewing Gum on Success in Quitting Smoking

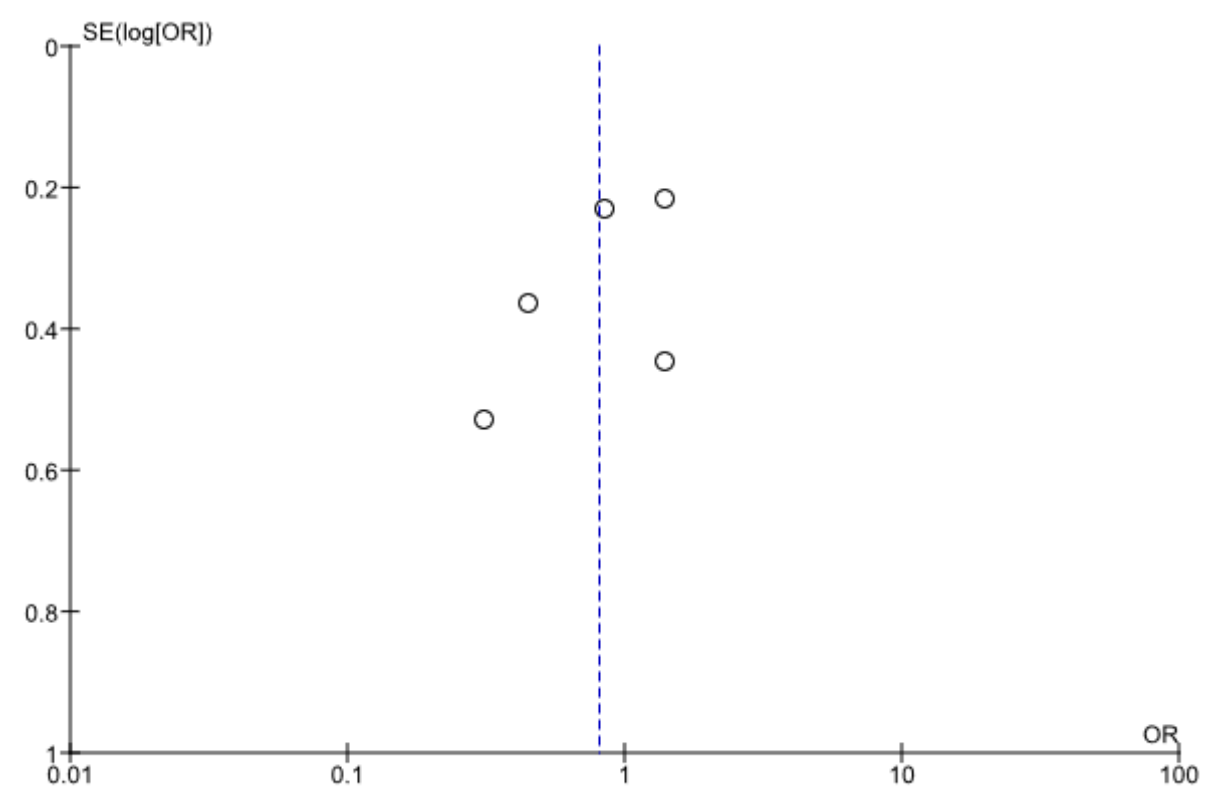

Figure 4. Funnel Plot Effect of Nicotine Chewing Gum on Success in Quitting Smoking

\section{DISCUSSION}

The article obtained in this cohort study stated that adult smokers who used nicotine gum could increase their successful smoking cessation behavior 0.81 times and could not help smokers quit smoking compared to placebo $(\mathrm{OR}=0.81 ; 95 \% \mathrm{CI}=$ 0.48 to $2.12 ; \mathrm{p}=0.400$ ) which can be seen in the results of the forest plot.

This research is supported by a systematic review study conducted by the National Institute for Health Research (2019) which found that those who used chewing gum and nicotine patches were more likely to quit smoking. Combination nicotine replacement therapy (NRT) increases the likelihood of long-term smoking cessation by approximately $25 \%$ compared with use of the single form. The comparison between the two was $14 \%$ (single NRT) and $17 \%$ combined NRT).

Similar results were also obtained in Denmark with the result that healthy smokers who were highly motivated to reduce cigarette use had a significantly higher overall success rate for reducing sustainable smoking at all time points for the use of artificial chewing gum compared to placebo but was more effective at reducing smoking. A combination of chew- 
ing gum and nicotine patches (Wennike, 2003)

The results of this study are not in line with the results of research conducted by Lindson et al. (2019) which stated that smokers who use nicotine gum have high benefits for quitting smoking.

Nicotine replacement therapy is a smoking cessation therapy that allows adult smokers to quit smoking. However, the existence of this therapy cannot be trusted by the public as happened in Africa and America. Smokers are less interested in quitting smoking because of the perceived side effects of the drug and the combined disadvantages of using tobacco products and nicotine substitutes smokers' perceptions of the ineffectiveness of smoking cessation aids (Pacek et al. 2021)

The lack of interest of smokers to quit smoking is also caused by several other factors such as what happened to Unair students who stated that their monthly pocket money, number of friends who smoked, and the presence of smokers in their residence did not significantly affect the motivation to quit smoking (Larasati et al 2018)

The combination of smokers' motivation to quit smoking and the use of nicotine replacement therapy is likely to help smokers to quit smoking. However, public knowledge about nicotine replacement therapy is still lacking. This happens to health practitioners, namely dentists in the city of Davangere who have little knowledge about NRT (Gaidhanker et al., 2020)

Lack of knowledge about smoking cessation also occurs in doctors in Armenia. Doctors are unable to provide support for smoking cessation due to poor knowledge of doctors about evidence-based smoking cessation methods (Harutyunyan et al., 2020)
Increasing public knowledge about smoking replacement therapy is very important, especially for health personnel so that they can provide support to patients in an effort to stop smoking.

\section{FUNDING AND SPONSORSHIP}

This study is self-funded.

\section{AUTHOR CONTRIBUTION}

Roni Hartono is the main researcher who selects topics, searches, collects research data and reviews research documents. Lina Eta Safitri plays a role in analyzing the data.

\section{CONFLICT OF INTEREST}

There is no conflict of interest in this study.

ACKNOWLEDGEMENT

We are very grateful to the database providers Google Scholar.

\section{REFERENCES}

Adam NT, Marris J (2020). Smoking. StatPearls.

Gaidhanker S, Sowmya, Preeti AB, Metha (2020). Knowledge, attitude, and implementation of nicotine replacement therapy by dental and medical interns in Davangere city: A crosssectional survey. J Indian Soc Periodontol 24(6): 567-571. https://doi.org/10.4103/jisp.jisp_28_19.

Harutyunyan A, Abrahamyan A, Grigoryan Z, Hayrumyan V, Truzyan N, Petrosyan V (2020). Smoking cessation knowledge, attitude and practices among tuberculosis physicians: A qualitative study. Tob. Prev. Cessation 6(70): 1-9. https://doi.org/10.18332$/ \mathrm{tpc} / 130475$

Kementerian Kesehatan Republik Indonesia. (2019). HTTS 2019: Jangan biarkan rokok merenggut napas kita (Don't let cigarettes take our breath). 
Hartono et al./ Nicotine Chewing Gum and Its Correlation with Smoking Cessation

Retrieved from https://www.kemenkes.go.id/article/view/19071100001/ htts2019janganbiarkanrokok-merenggutnapas-kita.html.

Larasati ER, Saraswati W, Setiawan HU, Rahma SS, Gianina A, Estherline CA, Nurmalasari F (2018). Motivasi berhenti merokok pada perokok dewasa muda berdasarkan transtheoretical Model (TTM). Jurnal Farmasi dan Ilmu Kefarmasian Indonesia. 5(2): 85-92. http://dx.doi.org/10.20473/jfiki.v5i22018.85-92.

Lindson N, Chepkin SC, Ye W, Fanshawe TR, Bullen C, Hartmann-Boyce J (2019). Different doses, durations and modes of delivery of nicotine replacement therapy for smoking cessation. Cochrane Database Syst Rev. 4(4): CD013308. https://doi.org/10.1002/14651858.cdo13308.

Martin LM, Sayette MA (2018). A review of the effects of nicotine on social functioning. Exp Clin Psyhopharmacol. 26(5): 425-439. https://doi.org/10.1037/phaoooo208.

National institute for Health Research (2019). Using both Nicotine Patches and gum together improves the chances of quitting smoking. National
Institute for Health Research. doi: 10.3310/signal-00786.

Pacek LR, Holloway AD, Cropsey KL, Meade CS, Sweitzer MM, Davis JM, McClernon J (2021). Experience with smoking cessation attempts and prior use of cessation ands in smoking with HIV: Findings from a Focus Gruup Study Conducted in Durham, North Carolina. AIDS Educ Prev. 33(2): 158168. https://doi/10.1521/aeap.2021.33.2.158.

Taringan, Yulianti A (2019). Gambaran kesadaran masyarakat terhadap kawasan tanpa rokok di Indonesia (An overview of public awareness of nonsmoking areas in Indonesia). Jurnal Penelitian dan Pengembangan Pelayanan Kesehatan. 2(3): 123-130. https://doi.org/10.22435/jpppk.v3i2. 2655.

Wennike $\mathrm{P}$, Danielsson $\mathrm{T}$, Landfedt $\mathrm{B}$, Westin A, Tonnesen P (2003). Smoking reduction promotes smoking cessation: results from a double blind, randomized, placebo-controlled trial of nicotine gum with 2-year follow-up. 98(10): 1395-1402. https://doi.org/10.1046/j.1360-0443.2003.00489.x. 